going bypass surgery. J Thorac Cardiovasc Surg 1985;90: 532.

25. Wohlgelertner D, Clenan M, Highman HA, Zaret BL. Percutaneous transluminal coronary angioplasty of the "culprit" lesion for management of unstable angina pectoris in patients with multivessel coronary artery disease. Am J Cardiol 1986; $58: 460$.
26. Meier B, Gruentzig AR, King SB III, Douglas JS, Hollman J, Ischinger I, Galan K. Higher balloon dilatation pressure in coronary angioplasty. AM HEART J 1984;107:619.

27. Grover FL, Hammermeister KE, Burchfiel C, and the VA Surgeons. Initial report of the VA pre-operative risk assessment study for cardiac surgery. Ann Thorac Surg (In press 1990)

\title{
Recovery of regional myocardial dysfunction after successful coronary angioplasty early after a non-Q wave myocardial infarction
}

\begin{abstract}
More aggressive therapy has been suggested for patients who have a non- $Q$ wave myocardial infarction (MI) because of the frequency of subsequent unstable angina, recurrent MI, and high mortality rate compared to patients with Q wave MI. The present study was undertaken to investigate the effect of coronary angioplasty on regional myocardial function of the infarct zone in patients with angina early after a non- $Q$ wave MI. The study population consisted of 36 patients undergoing successful coronary angioplasty within 30 days of a non- $Q$ wave MI, in whom sequential left ventricular angiograms of adequate quality were obtained before the initial procedure and at follow-up angiography. The global ejection fraction increased significantly from $60 \pm 9 \%$ to $67 \pm 6 \%(p=0.0003)$. This significant increase in the global ejection fraction was primarily due to a significant improvement in the regional myocardial function of the infarct zone. The results of the present study show not only that ischemic attacks early after a non-Q wave MI may lead to prolonged regional myocardial dysfunction but more important that this depressed myocardium has the potential to achieve normal contraction after successful coronary angioplasty. (AM HEART J 1990;120:261.)
\end{abstract}

Harry Suryapranata, MD, Patrick W. Serruys, MD, Kevin Beatt, MRCP, Pim J. De Feyter, MD, Marcel van den Brand, MD, and Jos Roelandt, MD.

Rotterdam, The Netherlands

The reported incidence of non-Q wave myocardial infarction (MI) varies between $20 \%$ and $36 \%$ of all acute MI. ${ }^{1-5}$ Although non- $Q$ and $Q$ wave $\mathrm{MI}$ as classified by ECG results cannot always be anatomically differentiated, ${ }^{6,7}$ it seems likely that they differ clinically, physiologically, and prognostically as discussed by Spodick. ${ }^{8}$ In particular, non- $Q$ wave $M I$ is generally associated with smaller amounts of myocardial necrosis, better left ventricular function, and a lower incidence of in-hospital death when com-

From the Thoraxcenter, University Hospital Rotterdam.

Received for publication June 21, 1989; accepted March 15, 1990.

Reprint requests: Harry Suryapranata, MD, Catheterization Laboratory, Thoraxcenter, University Hospital Rotterdam, Postbus 1738, 3000 DR Rotterdam, The Netherlands.

4/1/21135 pared to $Q$ wave MI. Despite these initially favorable features, evidence has accumulated that the longterm mortality rate in these patients is similar to or even greater than that in patients with $Q$ wave $M I$. The relatively high mortality rate of patients with non-Q wave $M I$ seems to be related to unstable angina or subsequent recurrent $\mathrm{MI}$ in the same area ${ }^{1-3,6,9-13}$ and may be prevented if recurrent MI can be averted with revascularization. These findings have understandably led some to recommend more aggressive evaluation and treatment strategies for survivors of non- $Q$ wave $M I$.

Results of previous studies have shown that regional myocardial dysfunction, observed during acute ischemic syndromes, improves after coronary blood flow is restored by coronary angioplasty. In the setting of preinfarction angina ${ }^{14}$ and in the first few 


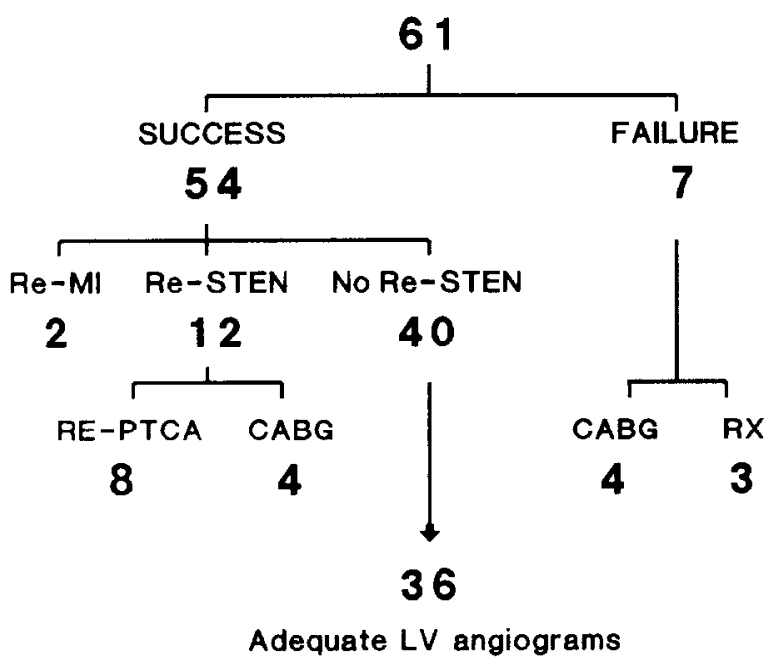

Fig. 1. Clinical follow-up data obtained at mean interval of 20 (range 3 to 59) months in patients who underwent early coronary anginplasty after sustained non-Q wave MI. Patients selected for study were those who underwent successful coronary angioplasty without angiographic restenosis (Re-Sten) or late major clinical events during follow-up and in whom sequential left ventricular $(L V)$ angiograms of sufficient quality were available. $R e-M I$, recurrent myocardial infarction; Re-PTCA, repeat coronary angioplasty; $C A B G$, coronary artery bypass surgery; $R x$, controlled by pharmacologic treatment.

hours of acute $\mathrm{MI},{ }^{15}$ reperfusion with coronary angioplasty has resulted in improvement in regional myocardial function. In contrast, the impact of therapeutic interventions in patients with postinfarction angina remains unsettled, particularly in patients with sustained non-Q wave MI. Although there have been several reports suggesting that revascularization with coronary angioplasty or coronary artery bypass surgery can be performed safely and effectively early in the course of non- $Q$ wave $M I,{ }^{16-20}$ the assessment of regional myocardial function in the infarct zone and the role of coronary angioplasty in salvaging function in this setting have not been established. The present study was therefore undertaken to investigate the effect of coronary angioplasty on regional myocardial function of the infarct zone in patients with angina early after a non-Q wave MI.

\section{METHODS}

Patients. Between January 1982 and January 1987, a total of 116 patients underwent coronary angioplasty for angina, either at rest or during submaximal exercise despite optimal pharmacologic therapy, after a non-Q wave MI. They represented $8 \%$ of our total coronary angioplasty population during this period. Of these 116 patients, 61 underwent early coronary angioplasty during
Table I. Clinical characteristics

\begin{tabular}{ll}
\hline \multicolumn{1}{c}{ Characteristics } \\
\hline No. & 36 \\
Men/women & $28 / 8$ \\
Age (median, yr) & 56 (range 32-72) \\
Anterior/inferior non-Q MI & $24 / 12$ \\
Peak CK enzyme level (median, U/L) & 389 (range 243-892) \\
Peak CK-MB (median, U/L) & 42 (range 12-94) \\
Stable angina pectoris & 7 \\
Unstable angina pectoris & 29 \\
Therapy before PTCA & \\
Triple therapy (intravenous NTG) & $34(16)^{*}$ \\
$\quad$ Double therapy & 2 \\
Time from MI to PTCA (median, days) & 14 (range 2-30) \\
\end{tabular}

CABG, coronary artery bypass graft; PTCA, percutaneous transluminal coronary angioplasty; MI, myocardial infarction; CK, creatinine phosphokinase; NTG, nitroglycerin.

* Optimal pharmacologic therapy consisted of beta blocker, calcium antag. onist, and nitrates, including 16 patients who were treated with intravenous nitroglycerin.

Table II. Angiographic characteristics

\begin{tabular}{lr}
\hline \multicolumn{1}{c}{ Characteristics } \\
\hline Single-vessel disease & $25(69 \%)$ \\
Multivessel disease & $11(31 \%)$ \\
Total occlusion & $5(14 \%)$ \\
Collateral circulation & $28(78 \%)$ \\
Single-vessel dilatation & $32(89 \%)$ \\
Multivessel dilatation & $4(11 \%)$ \\
Dilated coronary artery $(n=40)$ & \\
$\quad$ Left anterior descending & $25(62.5 \%)$ \\
Left circumflexus & $7(17.5 \%)$ \\
Right & $8(20 \%)$ \\
\hline
\end{tabular}

their hospital stay after sustained non-Q wave MI. The obstructed vessel was successfully dilated in 54 of the 61 patients $(89 \%)$. All patients were followed at the outpatient clinic. Clinical follow-up data obtained at a mean interval of 20 (range 3 to 59) months are shown in Fig. 1. Patients selected for the study were those who underwent successful coronary angioplasty early after a non- $Q$ wave MI without angiographic restenosis or late major clinical events during follow-up and in whom sequential left ventricular angiograms of sufficient quality to allow automated contour analysis before coronary angioplasty and at followup were available. Thirty-six patients fulfilled these criteria and formed our study population (Fig. 1). Clinical and angiographic data are summarized in Tables I and II.

Non-Q wave MI was defined in this study as prolonged chest pain compatible with acute MI, associated with electrocardiographic ST segment and $\mathrm{T}$ wave abnormalities without progression to pathologic $Q$ waves but with abnormal elevation of the creatinine kinase level (at least twice the normal value) before any intervention. Postinfarction angina was considered unstable if it occurred at rest, lasted for at least 15 minutes, and was associated with ECG evidence of myocardial ischemia without evidence of fur- 
A

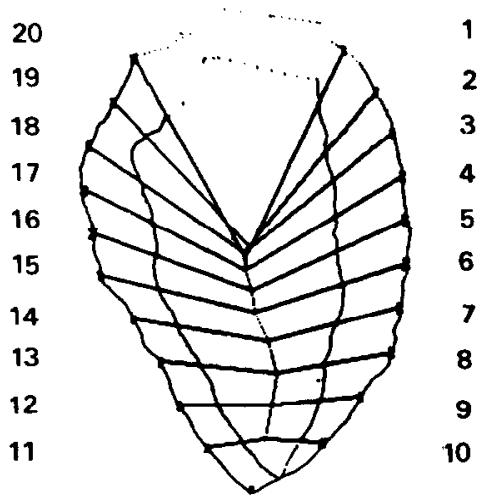

$\mathrm{B}$

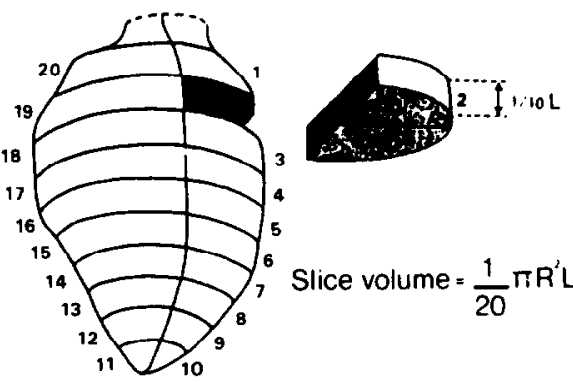

C

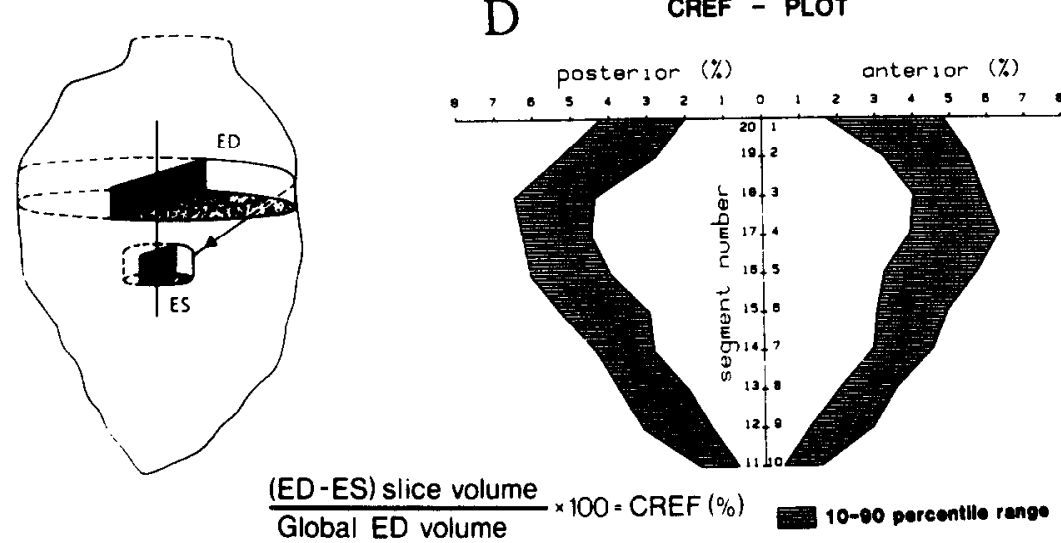

Fig. 2. A, Example of computer output showing end-diastolic and end-systolic contours of 30-degrec right anterior oblique view of left ventriculogram. Systolic regional wall displacement was determined along a system of 20 coordinates based on pattern of actual endocardial wall motion in normal individuals ${ }^{22}$ and generalized as mathematical expression amenable to automatic data processing. ${ }^{23,25} \mathbf{B}$, Left ventricular end-diastolic cavity is divided into 20 half slices. Volume of each half slice is computed according to given formula, $R$ is radius and $L$ is left ventricular long-axis length. C, Regional contribution to global ejection fraction (CREF) is determined from systolic decrease of volume of half slice, which corresponds to particular wall segment. Systolic volume change is mainly consequence of decrease of radius $(R)$ of half slice. When normalized for end-diastolic volume, systolic segmental volume change was considered as a parameter of regional pump function. D, Shaded zones represent tenth to ninetieth percentiles area of CREF values in normal individuals. $\mathrm{X}$ axis displays CREF values of anterior and inferoposterior wall areas (\%); $\mathrm{Y}$ axis shows segment numbers of anterior wall (1 to 10) and inferoposterior wall (11 to 20).

ther myocardial necrosis. Angioplasty was considered successful when a reduction in the severity of the obstruction to less than $50 \%$ luminal diameter narrowing was achieved with abolition of acute ischemic symptoms without progression to $\mathrm{MI}$, emergency surgery, or death. Restenosis at follow-up was defined as a decrease of $\geq 0.72 \mathrm{~mm}$ in $\mathrm{min}$ imal luminal diameter with respect to the postangioplasty situation. ${ }^{21}$ After the procedure patients were monitored for 24 hours in the medium-care unit. All were treated with $60 \mathrm{mg}$ nifedipine and $500 \mathrm{mg}$ acetylsalicylic acid daily over a period of 6 months. During this follow-up period six patients received additional beta blockers, three of them in combination with nitrates. Follow-up coronary and left ventricular angiography and exercise thallium-201 scintigraphy were performed at a mean of 5 months.
Quantitative analysis of left ventricular and coronary angiography. Global and regional left ventricular function was studied from the 30-degree right anterior oblique projection by means of an automated hard-wired endocardial contour detector. This method of analysis has previously been described in detail. ${ }^{22-25}$ The analysis of regional left ventricular function was based on automated, high-resolution, frame-to-frame edge detection of the left ventricular contour. This system allows fast and reliable acquisition of a single left ventricular contour, every $20 \mathrm{msec}$ ( 50 frames/ sec), all over a complete cardiac cycle. Fig. 2 shows examples of the end-diastolic and end-systolic contours of the left ventriculogram and the segmental contribution to the global ejection fraction as displayed by the analysis system. Quantitative analysis of the dilated coronary segment be- 
PTCA FOLLOWING NON-Q WAVE MI

ANTERIOR INFARCTION $(n: 24)$

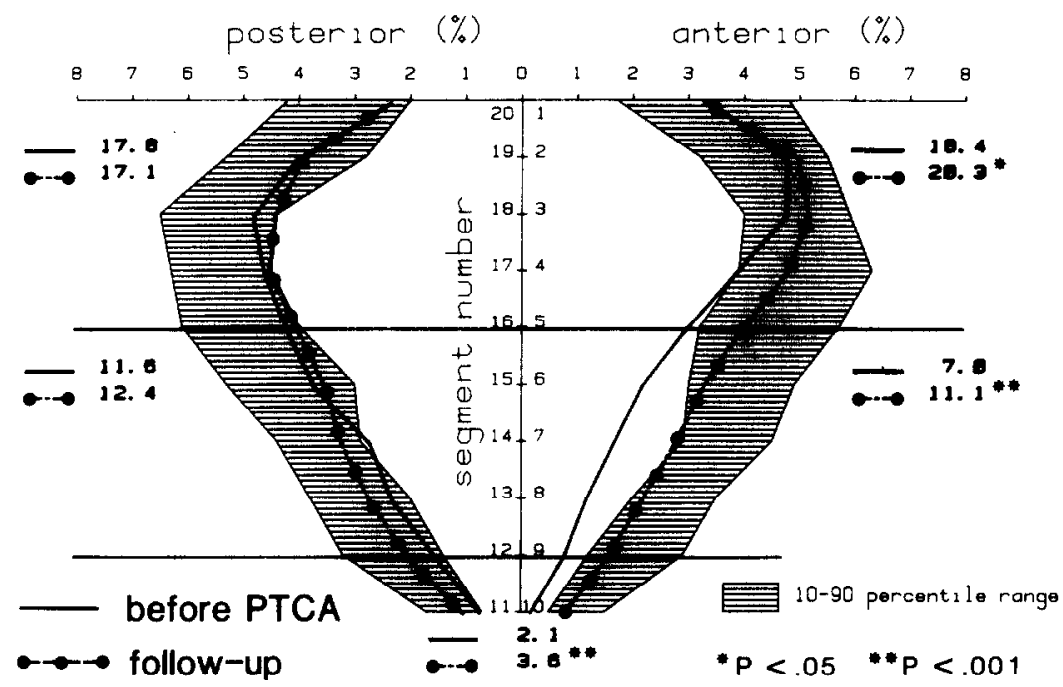

PTCA FOLLOWJNG NON-O WAVE MI INFERIOR INFARCTION ( $n: 12)$

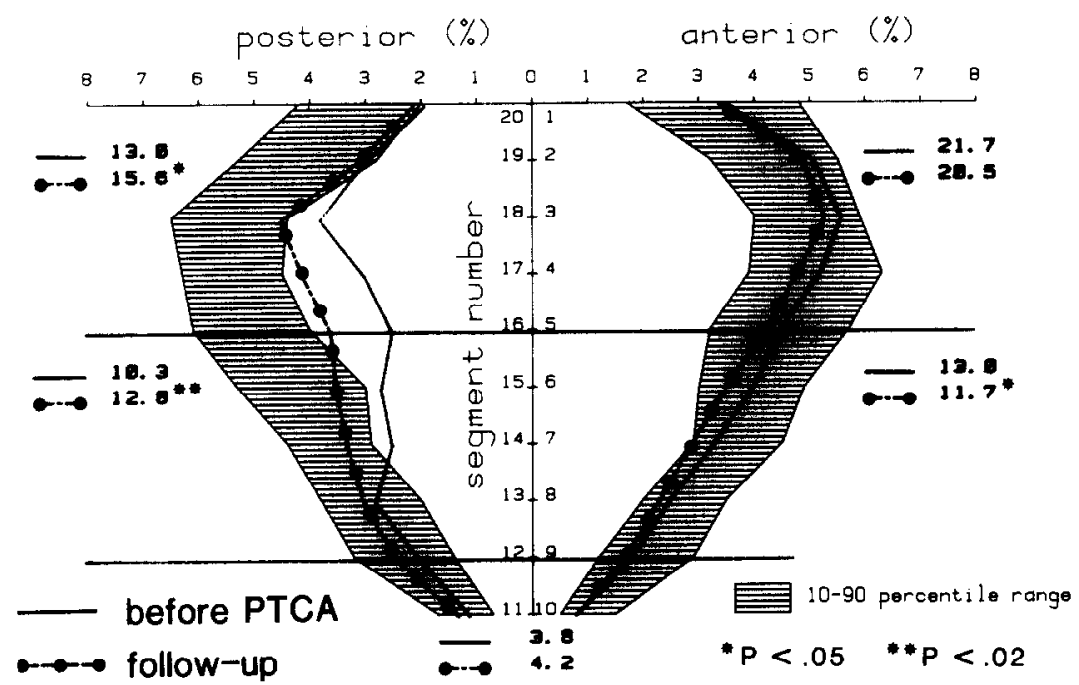

Fig. 3. Sequential changes in regional contribution to global ejection fraction, before angioplasty (solid line) and at follow-up angiography (dotted line), in patients with anterior (top) and inferior (bottom) non$Q$ wave MI undergoing successful coronary angioplasty. Initially depressed regional myocardial function of infarct zone has potential to achieve normal contraction after adequate reperfusion with coronary angioplasty, resulting in significant increase in global ejection fraction.

fore and after the angioplasty procedure and at follow-up coronary angiography was carried out with the computerassisted cardiovascular angiography analysis system, which has been described in detail previously. ${ }^{26,27}$

Exercise thallium-201 scintigraphy. Patients performed symptom-limited exercise on the bicycle ergometer with stepwise increments of $20 \mathrm{~W}$ every minute. The three orthogonal leads X,Y, and Z of the Frank lead system were recorded. An ischemic response was defined as at least a 0.1 $\mathrm{mV}$ ST segment depression occurring 0.08 second after the
J point. The maximal work load achieved was expressed as a percentage of the normal work load predicted for age, sex, and height. Thallium scintigraphic imaging was performed in the anterior, 45- and 65-degree left anterior oblique views, immediately after injection of $1.5 \mathrm{mCi}$ of thallium201 at peak stress. The postexercise images were obtained 4 hours later. Images were obtained with a Searle Phogamma V camera (G. D. Searle \& Co., Skokie, Ill.) and processed with computer interface as previously described. ${ }^{28}$ Defects with subsequent redistribution were considered to 
represent exercise-induced ischemia. Persistent defects without redistribution were considered to represent infarcted myocardium.

Statistics. Data are expressed as mean \pm standard deviation. Paired Student's $t$ tests were applied whenever appropriate. A $p$ value of less than 0.05 was considered significant.

\section{RESULTS}

Follow-up angiography was performed at a mean of 4.7 (range 2 to 8 ) months after initially successful coronary angioplasty. The mean diameter and area of stenosis of the dilated coronary artery, determined by means of a computer-assisted quantitative analysis, were respectively $59.4 \pm 10.6 \%$ and $83 \pm 17 \%$ before the angioplasty procedure, $32.8 \pm 8.7 \%$ and $53 \pm 11 \%$ immediately after angioplasty, and $36.6 \pm 7.7 \%$ and $59 \pm 10 \%$ at follow-up angiography.

Quantitative analysis of global and regional left ventricular function. Sequential changes in the global left ventricular function before coronary angioplasty and at follow-up angiography are summarized in Table III. There were no significant changes in heart rate, mean aortic pressure, end-diastolic pressure, and end-diastolic volume. The end-systolic volume, however, decreased significantly from 29 to $24 \mathrm{ml} / \mathrm{m}^{2}$, resulting in a significant increase in global ejection fraction from $60 \pm 9 \%$ to $67 \pm 6 \% \quad(p=0.0003)$. This significant increase in the global ejection fraction was primarily due to a significant improvement in the regional contribution to ejection fraction (CREF) of the infarct zone, as shown in Fig. 3. More detailed analysis of the regional myocardial function (Table IV) further demonstrated that the CREF values of the initially abnormal segments increased significantly from $12.6 \%$ to $20.1 \%$, whereas in those segments that were initially normal the regional myocardial function decreased.

Exercise thallium-201 scintigraphy. ECG exercise testing and thallium-201 scintigraphy were carried out in 33 patients (92\%), 4.5 (range 2 to 11 ) months after the angioplasty procedure (Fig. 4). A maximal work load of more than $80 \%$ predicted for age, sex, and height was achieved in $91 \%$ of the patients. Ninety-one percent of the patients were symptom free during exercise; ischemic ST-T segment depression was induced in $15 \%$, and a reversible thallium201 perfusion defect in the area supplied by the dilated vessel was documented in $18 \%$ of the patients.

\section{DISCUSSION}

Although there was a significant improvement in global ejection fraction in our patients, the crucial
Table III. Sequential changes in global left ventricular hemodynamics

\begin{tabular}{lccc}
\hline Hemodynamics & Before PTCA & Follow-up & $p$ Value \\
\hline HR (beats/min) & $70 \pm 12$ & $78 \pm 17$ & NS \\
MAP (mm Hg) & $82+12$ & $85+9$ & NS \\
EDP (mm Hg) & $23 \pm 10$ & $19 \pm 8$ & NS \\
EDV (ml/m²) & $73 \pm 17$ & $71 \pm 15$ & NS \\
ESV (ml $\left./ \mathrm{m}^{2}\right)$ & $29 \pm 12$ & $24 \pm 6$ & 0.006 \\
SV (ml $\left./ \mathrm{m}^{2}\right)$ & $44 \pm 12$ & $47 \pm 11$ & 0.08 \\
FF $(\%)$ & $60 \pm 9$ & $67 \pm 6$ & 0.0003 \\
CI $\left(\mathrm{L} / \mathrm{min} / \mathrm{m}^{2}\right)$ & $3.0 \pm 0.8$ & $3.1 \pm 0.8$ & NS \\
\hline
\end{tabular}

HR, heart rate; MAP, mean aortic pressure; EDP. end-diastolic pressure, $\mathrm{EDV}$, end-diastolic volume; ESV, end-systolic volume; SV, stroke volume; $\mathrm{EF}$, global ejection fraction; $\mathrm{CI}$, cardiac index; PTCA, percutaneous transluminal coronary angioplasty; NS, not significant.

Table IV. Quantitative assessment of regional contribution to global ejection fraction (CREF)

\begin{tabular}{cccc}
\hline & Before PTCA & Follow-up & $p$ Value \\
\hline $\begin{array}{c}\text { Sum of abnormal } \\
\text { CREF }(\%)\end{array}$ & $12.6 \pm 4.8$ & $20.1 \pm 7.7$ & $10^{-8}$ \\
$\begin{array}{c}\text { Sum of normal } \\
\text { CREF }(\%)\end{array}$ & $46.4 \pm 11.9$ & $44.5 \pm 11.9$ & 0.007 \\
\hline
\end{tabular}

question remains whether these differences can be ascribed to the salvage of previously jeopardized myocardium in the area supplied by dilated vessel. Therefore analysis of left ventricular wall motion in the area at risk must be carried out to detect any real benefit of correcting the obstructive lesion. In fact, increased motion of the nonischemic regions may keep the global ejection fraction within normal limits despite severe regional hypokinesia in the ischemic area. As this compensatory augmented motion in the nonischemic area usually subsides chronically, the global ejection fraction has proved to be an unreliable and insensitive measure of assessing either the severity of hypokinesia in an ischemic region or the effect of therapeutic interventions in salvaging function.

The present study constitutes the first analysis of the effect of coronary angioplasty on global and regional left ventricular function at rest in a series of patients with non- $Q$ wave $M I$. The results show that the initially depressed myocardium is capable of recovering function and has the potential to achieve normal contraction after adequate reperfusion with coronary angioplasty, resulting in a significant increase in global ejection fraction even after the disappearance of compensatory enhanced function of the nonischemic area. This suggests that in some patients reperfusion may need to be supplemented by 


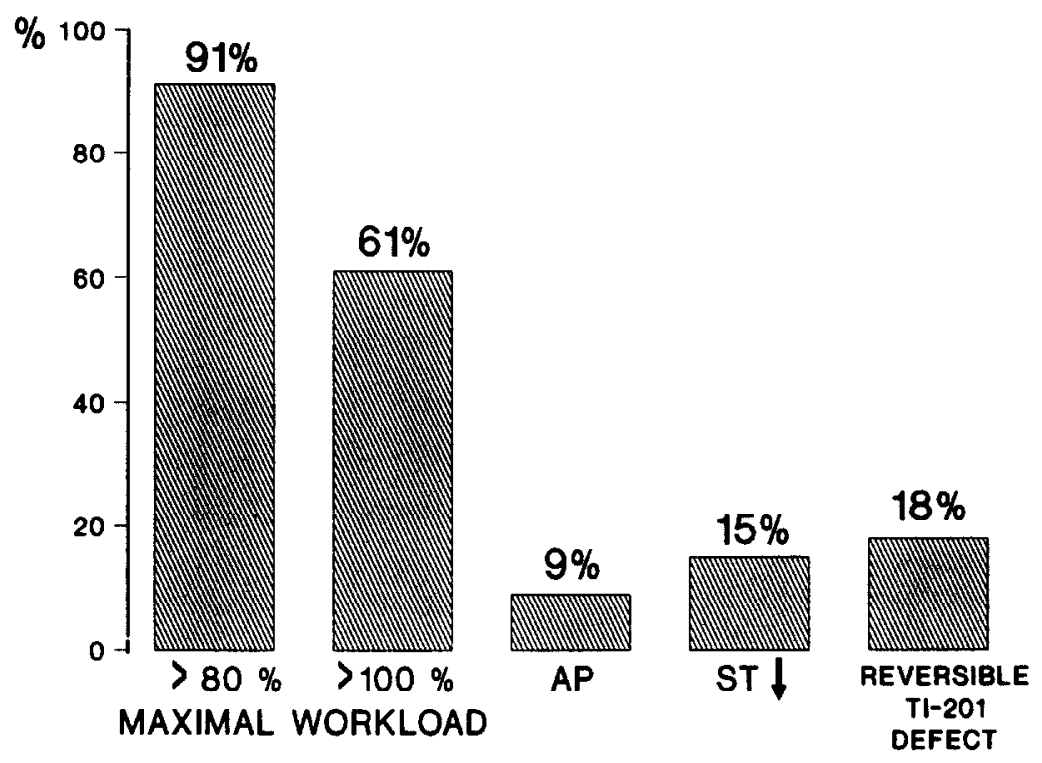

Fig. 4. Results of exercise thallium-201 scintigraphy $(n=33), 4.5$ (range 2 to 11 ) months after initially successful angioplasty. Maximal work load of $>80 \%$ and $>100 \%$ predicted for age, sex, and height was achieved in $91 \%$ and $61 \%$ of patients, respectively. Majority of patients $(91 \%)$ were symptom free during test; ST segment depression was documented in $15 \%$, and reversible thallium-201 perfusion defect in area supplied by dilated vessel was observed in $18 \%$ of patients.

an additional procedure such as angioplasty to optimize the chances of obtaining full functional recovery. The additional value of angioplasty in preserving left ventricular function might help to explain the observed low mortality rate and other major cardiac events. ${ }^{17}$

Factors influencing resting regional myocardial dysfunction. It has been shown experimentally that a severe reduction in coronary blood flow may result in loss of regional contractility without evidence of infarction. ${ }^{29,}{ }^{30}$ In the clinical setting it is important to appreciate these concepts, because the left ventricular dysfunction may be reversed by revascularization, resulting in reduced disability and improved survival. ${ }^{31}$ When myocardial perfusion is chronically reduced but is still sufficient to maintain the viability of the tissue, myocardial function may remain impaired permanently or for as long as myocardial perfusion is inadequate ("hibernating" myocardium). ${ }^{32}$ There is evidence that during low-flow ischemia, glucose metabolism is increased relative to fatty acid oxidation ${ }^{33,34}$ until flow is too low to permit washout of inhibitory end products of glucose metabolism. Continuation of glucose metabolism with subcritical reduction in blood flow may support cellular viability despite decreased regional myocardial contractility. It is thus possible that in patients with these features, this metabolic state may become chronic and clinically stable.

Chronic impairment of regional myocardial func- tion may also be due to repeated episodes of transient ischemia that are too brief to cause necrosis, leading to regional depletion of glycogen or high-energy phosphate stores, or they may be the result of reversible injury to other critical myocardial cellular processes that persists for prolonged periods after reperfusion. ${ }^{35}$ The return of contractile function in the salvaged tissue is not immediate but may require many days. This prolonged postischemic myocardial dysfunction has been referred to as "stunning" of the myocardium. Stunning also occurs as a consequence of longer periods of coronary occlusion in which the most intensively ischemic tissue, generally the subendocardium, undergoes irreversible damage, whereas large quantities of myocardium that are adjacent, usually epicardial, to the necrotic area may survive after reflow occurs. ${ }^{36}$ The fundamental mechanism responsible for myocardial stunning has not been definitively elucidated. The prolonged biochemical abnormality has been suggested as an explanation for the prolonged mechanical recovery; the adenosine triphosphate content of stunned tissue has been shown to be initially depressed by $50 \%$ with only partial recovery to $80 \%$ of normal within 3 days. ${ }^{37}$ Similarly a variety of other biochemical abnormalities have been postulated as the basis for the stunned myocardium: oxygen-derived free radicals, ${ }^{38} \mathrm{ab}$ normal calcium transport by the sarcoplasmic reticulum, ${ }^{39}$ interruption of the creatine phosphate shuttle, ${ }^{40}$ regional depletion of glycogen or high-en- 
ergy phosphate stores, and abnormalities of the cardiac sympathetic nerves. ${ }^{41}$

Although the natural history of the change in left ventricular function during the early course of acute non- $Q$ wave $M I$ has not been established, it is possible that the mechanisms of regional myocardial dysfunction in patients with non-Q wave MI may be due to a combination of both phenomena, since spontaneous coronary reperfusion after non- $Q$ wave $M I$ is common $^{4}$ and is frequently associated with subsequent unstable angina and recurrent MI. ${ }^{6,10,42}$ Results of several angiographic studies ${ }^{4,9,43-45}$ have shown that patients with non-Q wave $M I$ have a low incidence of totally occluded infarct-related vessel and a high incidence of collateral circulation to the area supplied by the infarct-related vessel. The essential finding of these studies is that some degree of perfusion, either antegrade or by means of collateral circulation, is present soon after a non- $Q$ wave MI, although it is insufficient to prevent the initial necrosis. In addition, it is possible that the impairment of contractile function that characterizes both stunned and hibernating myocardium serves as a protective mechanism in that it reduces the oxygen demands of the hypoperfused myocardium and thereby limits ischemia and necrosis. In the present study the incidence of open infarct-related vessel at the time of the angioplasty procedure was $86 \%$, and the incidence of collateral circulation to the infarct area was $78 \%$; all patients were symptomatic with $81 \%$ having unstable angina before angioplasty. In this situation the initially depressed regional myocardial function at rest in our series may be due to either chronic underperfusion of the myocardium, to prolonged mechanical recovery following episodes of transient ischemia after sustained non- $Q$ wave $M I$, or to both mechanisms. Whereas actual ischemia during baseline angiography as a possible explanation for the observed myocardial dysfunction seems unlikely, since no patients had angina in the laboratory and the mean time from the last attack of chest pain to left ventriculography before angioplasty was $38 \pm 27$ hours.

Limitations. On the other hand, there are several limitations to the study, and the results should be interpreted with this in mind. First, the results may be biased by the selection of patients and because the study was uncontrolled and involved only patients with non-Q wave $\mathrm{MI}$ with both recurrent anginal symptoms and anatomy suitable for coronary angioplasty. Therefore the results cannot be extrapolated to the majority of patients with non-Q wave $M I$. Comparison with the group in which angioplasty was not successful would be meaningless because of the limited number of patients and the high incidence of major clinical events with subsequent additional interventions in this unsuccessful angioplasty group (Fig. 1).

The lack of left ventricular angiograms immediately after successful angioplasty is another limitation of this study, inasmuch as it means we are unable to determine whether the initially depressed myocardium was due to prolonged postischemic dysfunction or to chronic underperfused myocardium. However, it is possible that left ventricular performance immediately after angioplasty could be influenced by catecholamine stimulation. ${ }^{46}$ Although the natural history of myocardial function in patients with non$Q$ wave $M I$ remains unsettled, regional myocardial dysfunction might improve spontaneously either as part of a natural healing process or as a result of pharmacologic therapy. ${ }^{47,48}$ Therefore randomization would have been desirable. However, it is diffcult to justify this type of study in our patient population, since these patients constitute a high-risk subgroup because of the presence of ongoing angina, either at rest or during submaximal exercise, despite optimal pharmacologic therapy. Such early postinfarction angina carries a poor short- and long-term prognosis. $1,6,9,42,49$

Although differences in pharmacologic treatment before and after the angioplasty procedure may also play a role in the observed difference in left ventricular function, results of the present study show that the regional wall motion improved selectively in the areas supplied by dilated artery rather than in the ventricle as a whole. We believe that the normalization of the antegrade flow after successful coronary angioplasty, as evidenced by repeat angiography, and the sustained symptomatic benefit with no signs of ischemia in the majority of the patients undergoing exercise thallium-201 scintigraphy, is the main reason for the observed recovery of myocardial function, although it is difficult to interpret the results of the thallium test because baseline thallium-201 scintigraphy was not performed.

Clinical implications. The salutary results of revascularization in patients with myocardial dysfunction emphasize the importance of detecting the reversibility of the regional myocardial dysfunction. Determining whether revascularization will improve abnormal resting wall motion has depended on the demonstration of reversible flow abnormalities on exercise thallium-201 scintigraphy ${ }^{50}$ or on evidence of improved wall motion after nitroglycerin infusion, ${ }^{51}$ with exercise ${ }^{52}$ or inotropic stimulus, such as postextrasystolic potentiation during contrast or radionuclide angiography, ${ }^{53}$ or the infusion of a sym- 
pathomimetic amine. ${ }^{54}$ Positron emission tomography has also been used to differentiate between normal, ischemic, and infarcted myocardium, as recently reported by several investigators. 55,56

Patients with non-Q wave $\mathrm{MI}$ appear to have more residual myocardial mass at risk as determined by exercise scintigraphy. ${ }^{4,9}$ By means of the F-18-deoxyglucose positron emission tomographic technique in 11 patients, it has been demonstrated that residual myocardial tissue viability in the infarct area is observed in $91 \%$ of patients with non-Q wave $\mathrm{MI}$ and in only $36 \%$ of the patients with $Q$ wave MI. ${ }^{57}$ These findings support the concept of myocardial salvage through recanalization to prevent further loss of myocardium, for one might postulate that these patients are left with an "incomplete MI" with an area of the myocardium "at risk" and might therefore benefit from revascularization of the relevant artery.

We thank the cardiac catheterization team of the Thoraxcenter and Claudia Sprenger de Rover for her secretarial assistance in the preparation of this manuscript.

\section{REFERENCES}

1. Marmor A, Sobel BE, Roberts R. Factors presaging early recurrent myocardial infarction ("extension"). Am J Cardiol 1981;48:603-10.

2. Marmor A, Geltman EM, Schechtman K, Sobel BE, Roberts R. Recurrent myocardial infarction. Clinical predictors and prognostic implications. Circulation 1982;66:415-21.

3. Maisel AS, Ahnve S, Gilpin E, Henning H, Goldberger AL, Collins D, Le Winter M, Ross Jr J. Prognosis after extension or myocardial infarct: the role of $Q$-wave or non-Q wave infarction. Circulation 1985;71:211-17.

4. Huey BL, Gheorghiade M, Crampton RS, Beller GA, Kaiser DL, Watson DD, Nygaard TW, Craddock GB, Sayre SL, Gibson RS. Acule non-Q wave myocardial infarction associated with early ST segment elevation: evidence for spontaneous coronary reperfusion and implications for thrombolytic trials. $J$ Am Coll Cardiol 1987;9:18-25.

5. Goldberg RJ, Gore JM, Alpert JS, Dalen JE. Non-Q wave myocardial infarction: recent changes in occurrence and prognosis-a community-wide perspective. AM HEART J 1987; 113:273-9

6. Hutter AM, De Sanctis RW, Flynn T, Yeatman LA. Nontransmural myocardial infarction: a comparison of hospital and late clinical course of patients with that of matched patients with transmural anterior and transmural inferior myocardial infarction. Am J Cardiol 1981;48:595-602.

7. Savage RM, Wagner GS, Ideker RE, Podolsky SA, Hackel DB. Correlation of postmortem anatomic findings with electrocardiographic changes in patients with myocardial infarction: retrospective study of patients with typical anterior and posterior infarcts. Circulation 1977;55:279-85.

8. Spodick DH. Q-wave infarction versus ST infarction: nonspecificity of electrocardiographic criteria for differentiating transmural and nontransmural lesions. Am J Cardiol 1983; 51:913-15.

9. Gibson RS, Beller GA, Gheorghiade M, Nygaard TW, Watson DD, Huey BL, Sayre SL, Kaiser DL. The prevalence and clinical significance of residual myocardial ischemia 2 weeks after uncomplicated non- $Q$ wave infarction: a prospective natural history study. Circulation 1986;73:1186-98.

10. Lekakis J, Katsoyanni K, Trichopoulos D, Tsitouris G. Q-ver- sus non- $Q$ wave myocardial infarction: clinical characteristics and 6-month prognosis. Clin Cardiol 1984;7:283-8.

11. Mahony C, Hindman MC, Aronin N, Wagner GS. Prognostic differences in subgroups of patients with electrocardiographic evidence of subendocardial or transmural myocardial infarction. Am J Med 1980;69:183-6.

12. Krone RJ, Friedman E, Thanavaro S, Miller JP, Kleiger RE Oliver GC. Long-term prognosis after first Q-wave (transmural) or non-Q-wave (nontransmural) myocardial infarction: analysis of 593 patients. Am J Cardiol 1983;52:234-9.

13. Hollander G, Ozick H, Greengart A, Shani J, Lichstein E. High mortality early reinfarction with first nontransmural myocardial infarction. AM HEART J 1984;108:1412-16.

14. de Feyter PJ, Suryapranata $H$, Serruys PW, Beatt K, van den Brand M. Hugenholtz PG. Effects of successful percutaneous transluminal coronary angioplasty on global and regional left ventricular function in unstable angina pectoris. Am J Cardiol 1987;60:993-7.

15. Suryapranata $H$, Serruys PW, de Feyter PJ, van den Brand M, Beatt K, van Domburg R, Kint PP, Hugenholtz PG. Coronary angioplasty immediately after thrombolysis in 115 consecutive patients with acute myocardial infarction. AM HEART J 1988:115:519-29.

16. Safian RD, Snyder LD, Synder BA, McKay RG, Lorell BH Aroesty JM, Pasternak RC, Bradley AB, Monrad ES, Baim DS. Usefulness of percutaneous transluminal coronary angioplasty for unstable angina pectoris after non- $Q$ wave acute myocardial infarction. Am J Cardiol 1987;59:263-6.

17. Suryapranata H, Beatt K, de Feyter PJ, Verrostte J, van den Brand M, Zijlstra F, Serruys PW. Percutaneous transluminal coronary angioplasty for angina pectoris after a non- $Q$ wave acute myocardial infarction. Am J Cardiol 1988;61:240-3.

18. Madigan NP, Rutherford BD, Barnhorst DA, Danielson GK Early saphenous vein grafting after subendocardial infarction: immediate surgical results and late prognosis. Circulation 1977;56(suppl II):1-3.

19. Aintablian A, Hamby RI, Weiss D, Hoffman I, Voleti CO, Wisoff BG. Results of aortocoronary bypass surgery grafting in patients with subendocardial infarction: late follow-up. Am J Cardiol 1978;42:183-6.

20. Williams DB, Ivey TD, Bailey WW, Irey SJ, Rideout JT, Stewart D. Postinfarction angina: results of early revascularization. J Am Coll Cardiol 1983;2:859-64.

21. Serruys PW, Luijten HE, Beatt KJ, Geuskens R, de Feyter PJ, van den Brand M, Reiber JHC, ten Katen HJ, van Es GA, Hugenholtz PG. Incidence of restenosis after successful coronary angioplasty: a time-related phenomenon. A quantitative angiographic study in 342 consecutive patients at 1,2,3, and 4 months. Circulation 1988:77:361-71.

22. Slager C.J, Hooghoudt TEH, Reiber JHC, Schuurbiers JCH Booman F, Meester GT. Left ventricular segmentation from anatomical landmark trajectories and its application to wall motion analysis. Comput Cardiol IEEE Comput Soc 1979;34750.

23. Hooghoudt TEH, Slager CJ, Reiber JHC, Serruys PW, Schuurbiers JCH, Meester GT, Hugenholtz PG. "Regional contribution to global ejection fraction" used to assess the applicability of a new wall motion model in patients with asynergy. Comput Cardiol IEEE Comput Soc 1980;253-6.

24. Serruys PW, Wijns W, van den Brand M, Mey S, Slager CJ, Schuurbiers JCH, Hugenholtz PG, Brower RW. Left ventricular performance, regional blood flow, wall motion and lactate metabolism during transluminal angioplasty. Circulation 1984;70:25-36

25. Slager CJ, Hooghoudt TEH, Serruys PW, Schuurbiers JCH, Reiber JHC, Meester GT, Verdouw PD, Hugenholtz PG. Quantitative assessment of regional left ventricular motion using endocardial landmarks. I Am Coll Cardiol 1986;7:31726.

26. Serruys PW, Reiber JHC, Wijns W, van den Brand M, Kooijman CJ, ten Katen HJ, Hugenholtz PG. Assessment of percutaneous transluminal coronary angioplasty by quantita- 
tive coronary angiography: diameter versus densitometric area measurements. Am J Cardiol 1984;54:482-8.

27. Reiber JHC, Serruys PW, Kooijman CJ, Wijns W, Slager CJ, Gerbrands JJ, Schuurbiers JCH, den Boer A, Hugenholtz PG. Assessment of short-, medium- and long-term variations in arterial dimensions from computer-assisted quantitation of coronary cineangiograms. Circulation 1985;71:280-8.

28. Wijns W, Serruys PW, Reiber JHC, de Feyter PJ, van den Brand M, Simoons ML, Hugenholtz PG. Early detection of restenosis after successful percutaneous transluminal coronary angioplasty by exercise-redistribution thallium scintigraphy. Am J Cardiol 1985;55:357-61.

29. Heyndrickx GR, Baig H, Nellens D, Leusen MC, Fishbein MC, Vatner SF. Depression of regional blood flow and wall thickening after brief coronary occlusion. Am J Physiol 1978; 234:653-9.

30. Vatner SF. Correlation between acute reductions in myocardial blood flow and function in conscious dogs. Circ Res 1980;47:201-7.

31. Braunwald E, Rutherford JD. Reversible ischemic left ventricular dysfunction: evidence for the "hibernating myocardium." J Am Coll Cardiol 1986;8:1467-70.

32. Rahimtoola SH. A perspective on the three large multicenter randomized clinical trials of coronary bypass surgery for chronic stable angina. Circulation 1985;72(suppl V):123-35.

33. Opie LH. Effects of regional ischemia on metabolism of glucose and fatty acids: relative rates of aerobic and anaerobic energy production during myocardial infarction and comparison with effects of anoxia. Circ Res 1976;38(suppl I):152-68.

34. Liedtke AJ. Alterations of carbohydrate and lipid metabolism in the acutely ischemic heart. Prog Cardiovasc Dis 1981;23: 321-36.

35. Braunwald E, Kloner RA. The stunned myocardium: prolonged, postischemic ventricular dysfunction. Circulation $1982 ; 66: 1146-9$.

36. Ellis SG, Henschke CI, Sandor T, Wynne J, Braunwald E, Kloner RA. Time course of functional and biochemical recovery of myocardium salvaged by reperfusion. J Am Coll Cardiol 1983;1:1047-55.

37. De Boer LWV, Ingwall JS, Kloner RA, Braunwald E. Prolonged derangements of canine myocardial purine metabolism after a brief coronary artery occlusion not associated with anatomic evidence of necrosis. Proc Natl Acad Sci IJSA 1980;77:5471-5.

38. Przyklenk K, Kloner RA. Superoxide dismutase plus catalase improve contractile function in the canine model of the "stunned myocardium." Circ Res 1986;58:148-56.

39. Krauss S, Hess ML. Characterization of cardiac sarcoplasmic reticulum dysfunction during short term normothermic, global ischemia. Circ Res 1984;30:129-43.

40. Greenfield RA, Swain JL. Dissociation of creatine kinase from the myofibril: disruption of the creatine phosphate shuttle as a potential mechanism for post-ischemic dysfunction [Abstract]. Circulation 1984;70(suppl II):82.

41. Ciuffo AA, Ouyang P, Becker LC, Weisfeldt ML. Reduction of sympathetic inotropic response after ischemia in dogs: contributor to stunned myocardium. J Clin Invest 1985;75: 1504-9.

42. Cannom DS, Levy W, Cohen LS. The short- and long-term prognosis of patients with transmural and nontransmural myocardial infarction. Am J Med 1976;61:452-8.

43. De Wood MA, Stifter WF, Simpson CS, Spores J, Eugster GS, Judge TP, Hinnen ML. Coronary arteriographic findings soon after non-Q wave myocardial infarction. $N$ Engl J Med 1986;315:417-23.

44. Nicholson MR, Roubin GS, Bernstein L, Harris PJ, Kelly DT. Prognosis after initial non- $Q$ wave myocardial infarction related to coronary arterial anatomy. Am J Cardiol 1983; 52:462-5.

45. Madigan NP, Rutherford BD, Frye RL. The clinical course, early prognosis and coronary anatomy of subendocardial infarction. Am J Med 1976;60:634-41.

46. Boudoulas H, Lewis RP, Vasko JS, Karayannacos PE, Beaver $B M$. Left ventricular function and adrenergic hyperactivity before and after saphenous vein bypass. Circulation 1976; 53:802-6

47. Boden WE, Gibson RS, Fenton S, Ruble P, Beller GA. Spontaneous improvement in left ventricular function during the early course of acute non- $Q$ wave myocardial infarction: evidence for "stunned myocardium?" J Am Coll Cardiol 1988;11:188A.

48. Nixon JV, Brown CN, Smitherman TC. Identification of transient and persistent segmental wall motion abnormalities in patients with unstable angina by two-dimensional echocardiography. Circulation 1982;65:1497.

49. Gibson RS, Borden WE, Théroux P, Strauss HD, Pratt CM, Gheorghiade M, Capone RJ, Crawford MH, Schlant RC, Kleiger RE, Young PH, Schechtman K, Perryman MB, Roberts $R$, and the Diltiazem Reinfarction Study Group. Diltiazem and reinfarction in patients with non-Q-wave myocardial infarction: results of a double-blind, randomized multicenter trial. N Engl J Med 1986;315:423-9.

50. Brundage BH, Massie BM, Botvinick EH. Improved regional ventricular function after successful surgical revascularization. J Am Coll Cardiol 1984;3:902-8.

51. Bodenheimer MM, Banka VS, Hermann GA, Trout RG, Pasdar H, Helfant RH. Reversible asynergy: histopathology and electrographic correlations in patients with coronary heart disease. Circulation 1976;53:792-6.

52. Rozanski A, Berman D, Gray R, et al. Preoperative prediction of reversible myocardial asynergy by postexercise radionuclide ventriculography. N Engl J Med 1982;307:212-16.

53. Popio KA, Gorlin R, Bechtel D, Levine JA. Postextrasystolic potentiation as a predictor of potential myocardial viability: preoperative analyses compared with studies after coronary hypass surgery. Am J Cardiol 1977;39:944-53.

54. Nesto RW, Cohn LH, Collins Jr JJ, Wynne J, Holman L, Cohn PF. Inotropic contractile reserve: a useful predictor of increased 5 year survival and improved postoperative left ventricular function in patients with coronary artery disease and reduced ejection fraction. Am J Cardiol 1982;50:39-44.

55. Marshall RC, Tillisch JH, Phelps ME, et al. Identification and differentiation of resting myocardial ischemia and infarction in man with positron computed tomography: ${ }^{18} \mathrm{~F}$-labeled flurodeoxyglucose and $\mathrm{N}-13$ ammonia. Circulation 1983; 67:766-78.

56. Tillisch .J, Brunken R, Marshall R, Schwaiger M, Mandelkorn M, Phelps M, Schelbert H. Reversibility of cardiac wall motion abnormalities predicted by positron tomography. N Engl J Med 1986;314:884-8.

57. Hashimoto T, Kambara H, Fudo T, Hayashi M, Tamaki S, Tokunaga S, Tamaki N, Yonekura Y, Konishi J, Kawai C. Non- $Q$ wave versus $Q$ wave myocardial infarction: regional myocardial metabolism and blood flow assessed by positron emission tomography. J Am Coll Cardiol 1988;12:88-93. 